\title{
ANALYSIS ON INDONESIA'S FULLFILLMENT OF OBLIGATIONS RISING FROM INTERNATIONAL TREATIES
}

\author{
Agustina Merdekawati** $^{*}$ and Andi Sandi Ant.T.T ${ }^{* * *}$
}

International Law Department and Constitutional Law Department

Faculty of Law, Universitas Gadjah Mada, Yogyakarta

Jalan Sosio Yustisia 1, Bulaksumur, Sleman, D.I. Yogyakarta 55281

\begin{abstract}
This research aims to examine the positions of international law and the applicable principles regarding the issues of fulfillment of international obligations under ratified/acceded international agreements by Indonesia. Upon assessment, this research concludes that: Firstly, there are two main obligations that should be fulfilled by Indonesia in an international agreement and treaties, which is legal obligation and moral obligation. Secondly, practices shown that Indonesia's commitments in fulfilling its international obligation are still not optimal, as a solution, it is recommended that future ratification of international agreement should include additional executorial / performance provision either in the form of Law or Presidential Regulation.
\end{abstract}

Keywords: international treaties, the fulfillment of legal obligation.

\section{Intisari}

Penelitian ini bertujuan untuk mengetahui bagaimana ketentuan hukum internasional mengatur persoalan kewajiban hukum negara terhadap pemenuhan perjanjian internasional yang telah diratifikasi/diaksesi dan untuk mengetahui bagaimana praktik yang Indonesia terkait pemenuhan kewajiban tersebut. Hasil pembahasan menunjukkan bahwa: Pertama, bahwa terdapat 2 kewajiban yang harus dilakukan oleh setiap negara pihak terkait dengan pemenuhan Perjanjian Internasional yakni kewajiban hukum dan kewajiban moral. Kedua, bahwa praktik pelaksanaan kewajiban pemenuhan Perjanjian Internasional di Indonesia masih kurang optimal dan sebagai solusinya dapat ditambahkan beberapa penegasan untuk pemenuhan berbagai kewajiban tersebut dalam bentuk penambahan klausula dalam produk pengesahan perjanjian internasional baik yang berupa Undang-Undang Ratifikasi maupun Peraturan Presiden.

Kata Kunci: perjanjian internasional, pemenuhan kewajiban hukum.

\section{Pokok Muatan}

A. Background 498

B. Research Method 499

C. Result and Analysis 500

1. Legal Obligation 500

2. Moral Obligation 580

D. Conclusion and Recommendation 509

This Research is a part of the Cross-Disciplinary Research and Social Service Program by Faculty of Law UGM.

** Correspondence address: agustina_merdekawati@ugm.ac.id.

**** Correspondence address: andi.sandi@ugm.ac.id. 


\section{A. Background}

The interaction between states in this globalized era are unavoidable, which in consequence, interaction between the framework of international law and national law has also substantially increased. Such fact are also true for Indonesia, as Indonesia have also become increasingly exposed and active in the international environment, as seen in The Treaty Index published by the Indonesia's Ministry of Foreign Affairs which notes that in 2016 Indonesia is a state party to 4872 international agreements. ${ }^{1}$ Which itself is a testament to Indonesia's participation in the international sphere.

Law No. 24 Year $2000^{2}$ expressly regulates the procedures of Indonesia's participation in international treaties either through signing, ratifying, exchange of treaty documents/diplomatic memorandums or through any other means agreed upon by the parties to an international treaty. However the Law does not specifically regulate the minimum obligations that is ensured to be performed or executed upon its express commitment to be bound by an international treaty.

Article 9 paragraph (2) of the Law only explains the forms of ratification of international treaties, which are either in the form of a Law or a Presidential Regulations. ${ }^{3}$ This is also the case in Law No. 12 of $2011^{4}$ regarding Formulation of Legislation which only regulates the promulgation and dissemination of laws including the laws on Ratification of International treaties, but do not regulate on the obligation of performance following ratification/accession.

This condition is understandable as many lawmakers assume that an international treaty is a form of contract between the parties where the rights and obligations of the parties are automatically regulated in detail in the treaty itself, therefore lawmakers assumed that there is the lack of need for specific regulation to set out the scheme of performance of international treaty that had been ratified by Government of Indonesia.

That understanding are not entirely wrong however it is inappropriate if applied in the national law framework, especially in Indonesia. This is due to the circumstances in Indonesia that in regard to international Agreements and Treaties there has been no consensus on means of application, thus international treaties that had been ratified in the present case rarely bear the same legal obligation and urgency to perform them compared to contractual obligation.

This ambiguity was primarily caused by the differing views in treatment of legal products that are based on ratification/accretion international agreement, these differing views amounted into 2 prominent perspective:

1. First Perspective, Ratified international agreement and treaties are integrated as a part of applicable national law immediately and automatically upon the product of ratification are made or declared by the Government of Indonesia

2. Second Perspective, International agreements and treaties are only applicable in thenational levelaftersuch products had undergone transformation into a national instrument. which requires the substance and content of this agreement/treaty to be made into Indonesian national law/legislation.

Both of these views exists to date in Indonesia, and contributed to the inconsistency of practice of application of international treaties in Indonesia. This dilemma are further obfuscated by

Basis Data Perjanjian Internasional, Indonesia Foreign Ministry, , accessed November 2016.

Law No. 24 of 2000 of the Republic of Indonesia regarding International Treaties (State Gazette of The Republic of Indonesia Year 2000 Number 185, Supplement to State Gazette of The Republic of Indonesia Number 4012).

See Law No.10 of 2004 regarding Establishment of Legislation (State Gazette of The Republic of Indonesia Year 2004 Number 53, Supplement to State Gazette of The Republic of Indonesia Number 4389), terminology of "Keputusan Presiden" has been changed to "Peraturan Presiden". Law No. 12 of 2011 regarding Establishment of Legislation (State Gazette of The Republic of Indonesia Year 2011 Number 82, Supplement to State Gazette of The Republic of Indonesia Number 5234). 
the fact that the Indonesian Constitution does not implies a particular stance or position in regard to application of international treaties. Unlike the United States of America where her constitution in Article VI of The United States Constitution set out America's position on the application of international treaties. ${ }^{5}$ Thus showing clarity to the question of rights and obligation of the parties to a treaty, parties to such treaty are also empowered to direct the application with ease as it allows direct application of clause straight out of the treaty and agreements, in consequence to this clarity, it is also allow ease of measurement on whether or not a state party has performed its treaty obligation as it enable clear monochromatic facts.

This is wholly different in the practices of practical application of an international treaty in Indonesia, where there is no unified understanding on actual, practical performance of a ratified international treaties or agreements. Practices seems to imply that the process of performance of international obligation ends at ratification, there are no legal means of ensuring performance of obligation following the ratification. In several circumstances ratification of treaties or agreements are simply an avenue for political purposes, and not based as an actual need to international regulations.

This condition surely is in contrary with the nature of ratification which is an act of commitment of a State's participation towards an international treaty, in the present framework sent the where consequences are that the provisions of the treaty can be enforced and accepted in the Indonesian legal system instead of Article 27 of the 1969 Vienna Convention ${ }^{6}$ which states that "A party may not invoke the provisions of its internal law as justification for its failure to perform a treaty. This rule is without prejudice to article $46 "{ }^{7}$

In this research, the authors attempt to offer an alternative solution in bridging the disarray in the frameworks of implementation of international treaties and to ensure that there exists guarantees for the fulfillment of international treaties that have been ratified/accessed by the government of Indonesia. The authors feel the need to stress the approach for this problem should not be resolved through amendment of the constitution as undertaking such effort would be tedious and relatively harder to take.

In the same time, this disarray in the implementation of international treaties must be done immediately. Thus the initial step of this research is to identify the general obligations that arise as a consequence of participation in international treaties and comparing the prevailing practices in Indonesia, and offering alternative solutions to overcome the gaps that exist between the requirement stipulated in the norms, and existing practices.

Based on the background provided, the authors are interested in assessing/studying further, with the research problems as follows: How does the current practice in Indonesia relating to the issue of the obligation of Indonesia in towards fulfilling international treaties that have been ratified/acceded and what are possible alternative solutions?

\section{B. Research Method}

Based on its field falls, this research is categorized as Legal Research which involves the process of finding the rule of law, principles of law, as well as legal doctrines in order to answer the legal issues faced. ${ }^{8}$ And in essence this research purports as applied research. As this research are conducted with the intention of finding results that are directly

\footnotetext{
Constitution and the laws of the United States which shall be made in Pursuance thereof; and all Treaties made, or which shall be made, under the Authority of the United States, shall be the supreme Law of the Land. See Robert E. Dalton, 2006, National Treaty Law and Practice, Martinus Nijhoff Publishers, Leiden, p. 788.

The Vienna Convention on The Law of Treaties (VCLT) adopted on 22 may 1969 and opened for signature on 23 may 1969.

Article 46 states that" A state may not invoke the fact that its consent to be bound by a treaty has been expressed in violation of a provision of its internal law regarding competence to conclude treaties as invalidating its consent unless that violation was manifest and concerned a rule of its internal law of fundamental importance".

8 Peter Mahmud Marzuki, 2010, Penelitian Hukum, Kencana Prenada Media Group, Jakarta, p. 35.
} 
applicable in practice of policy making in relation to effective enforcement of international treaties in Indonesia's legal system. ${ }^{9}$

The primary legal materials which is referring to the prevailing law authoritative in this regard (Specifically national law refered to Article 7 of Law No. 12 of 2011 on the Establishment of Laws and Regulations and under International law, which is the provisions stipulated in Article 38 (1) of the Statute of the International Court. And the Secondary legal materials shall refer to textbooks and journals. This research shall use 3 methods of research which is statutory approach, comparative approach and case based approach.

\section{Result and Analysis}

An important point that authors emphasize in this assessing the international treaties/agreement compliance practice in Indonesia, is to analyse whether the legal obligation had been implemented, and to analyse the reason behind non-compliance, which consequently calls , Indonesia description on the practice of Compliance to International Treaties that have been ratified/acceded by the Government of Indonesia is to see whether the various obligations of the treaty has been implemented by the Government of Indonesia or not, to analyse why the conditions and try to offer where the fulfilment of international treaty obligations can be met. Below is the detailed discussion on the practise of the Fulfillment of the International Treaty Obligations of the Government of the Republic of Indonesia as the Legal Consequences for Taking a Part in the International Treaty.

\section{Legal Obligation}

a. Respecting and Upholding the Provisions of The International Treaty and Implementing Them in Good Faith

The necessity in respecting and upholding the provisions of a treaty is an application of the principle of Pacta Sunt Servanda. Pacta Sunt Servanda is a general principle, which requires states to comply with all provisions stipulated in international treaties. These principles is inherently embedded within all agreement whether it was professed explicitly, implicitly or otherwise not referred at all. In practice the principle of Pacta Sunt Servanda are always linked with the good faith principle.

Good Faith, derived from the term Bona fides is often understood as a situation "free from the intent to deceive." 10 This is further affirmed by William W. Park which states that State Parties in an international treaty must not only carry out obligations provided by the treaty, but must implement them with no malicious intent. ${ }^{11}$ This principle of commitment to fulfill an obligation constitutes a non-negotiable foundation of international agreement in all legal systems, though interpretation may vary. ${ }^{12}$

In Indonesia, implementation of an international obligation and commitments can be examined through two perspectives, which is in the perspective of national legislation and practical perspective. From the perspective of national legislation it can be seen that the Indonesia indeed advocated Good Faith in implementing its obligation as observed in Article 4 of Act No. 24 of 2000. Article 4 also calls for an active participation from the state, meaning that the state should actively create or attempt to create concrete avenues of implementation of international treaties. Unfortunately there are no concrete measurements and definition of what constitutes as good faith under Indonesia's legal regime.

\footnotetext{
Sunaryati Hartono, 2006, Penelitian Hukum di Indonesia Pada Akhir Abad Ke-20, Alumni, Bandung, p. 101.

John Simpson and Edmund Weiner (eds), 1991, The Oxford English Dictionary (2 nd ed), Oxford University Press, Oxford, p. 754

William W. Park, "Treaty Obligation and National Law", Hastings Law Review, Vol. 58, No. 1, 2012, p. 251

Gerhard Von Glahn, 2013, Law Among Nations: An Introduction to Public International Law, Longman, Boston, p. 178.
} 
Thus the authors refers to good faith that are referenced in International Law Commission (ILC), which defined Good Faith as the rule that state parties that entered into an international agreement or commitments, shall not act in a manner that would prevent of execution or implementation of the treaty. ${ }^{13}$ I Wayan Parthiana opined that the obligation to implement an international treaty in good faith is seen from the behavior of a State that:

1. Implement the terms of the treaty in accordance with the contents, the essence, the intent and purpose of the treaty itself;

2. Respect the rights and obligations of other State Parties or third parties that were accorded rights and obligations.

3. Do not conduct actions that could impede efforts to achieve the objectives of the treaty, before and after the treaty came into force. ${ }^{14}$

It can be concluded that the fulfillment of good faith rely on the whether or not the state parties had implement the treaty factually, and can only be seen to observation of actual practice. As long as the state do not commit internationally wrongful act as set under ARSIWA, the state could be considered still within the corridor of implementation of international treaty in good faith. This principle offers an a contrario interpretation that implies that passive good faith tolerates a non-fulfillment, as long as such nonfulfillment does not adversely affect or cause damages to third party or other states, and fulfills individual demands of state parties.

The a quo assumption are further solidified by the fact that Indonesia have never been claimed against by other states in International Court of Justice or any other forums adjudicating violations borne out of international treaties. However, it does not mean that Indonesia has always implemented her international obligation, but there are proof that good faith non-performance would suffice.

One case in Indonesia that can serve as an example of non-implemention of obligation of the treaty in good faith is in the Case of Navigation Maritime Bulgare (NMB) v. PT. Nizwar. ${ }^{15}$ This case is a dispute regarding the enforcement of London arbitration award between PT Nizwar, subject to the laws of Indonesia and Navigation Maritime Bulgare, subject to the laws of Bulgaria. Both Indonesia and the United Kingdom are members of the Convention. In that case, Central Jakarta District Court does not acknowledge the award rendered by the Arbitration Court of London and thus are not executable. ${ }^{16}$

The above case illustrate the negative practice of treaty implementation in Indonesia which is highly unintegrated, whereas Indonesia should've been in the position of those who are burdened with the obligation to accommodate in so far international obligation existing, instead had been disconnected from the issues altogether.

One of the reasons that led to the

Sumaryo Suryokusumo, 2007, Studi Kasus Hukum Internasional, Penerbit Tatanusa, Jakarta, p. 42.

I Wayan Parthiana, 2005, Hukum Perjanjian Internasional Bagian 2, Mandar Maju, Bandung, p. 20.

International treaties are considered to be implemented in good faith in this case is the New York Convention 1958 (Convention on the Recognition and Enforcementn of Foreign arbitral awards) which Indonesia ratified by Presidential Decree No. 34 of 1981 on August 5 , 1981. This Convention broadly contains contains about liability recognition and enforcement of foreign arbitral awards. The most important matter in this Convention is the provision in Article III that contains an obligation for each participating country to recognize and respect tie every foreign arbitral awards including the execution of that decision.

16 Details are summarized cases of exposure of cases quoted from Wisnu Aryo Dewanto, "Difficult to Implement the Law Review Regarding Foreign Arbitral Awards In Indonesia", Yustika Journal, Vol. 7, No. 2, December 2004 and Suleman Coal, "Rejection of Foreign Arbitral Awards in Indonesia (Study of PT Nizwar v. Navigation Maritime Bulgare)", http://batubarasuleman.blogspot.com/2010/11/penolakanputusan-arbitrase-asing-di.html, accessed on 27 Desember 2013. 
Supreme Court rejection to implement the Convention on the Recognition and Enforcementn of Foreign Arbitral Awards, 1958 which has been ratified by Indonesia through Presidential Regulation No. 34 of 1981 on August 5, 1981. Is primarily the view of the Indonesian judge that sees that norms of international law can only be valid and applicable within national courts after going through a process of transformation, in which the substance of the treaty must be translated into national legislation. The mere existence of Presidential Regulation No. 34 of 1981 does not necessarily make the provisions of the Convention on the Recognition and Enforcement of Foreign Arbitral Awards applicable in Indonesia. This view tends to put international treaties that have been ratified/acceded Indonesia as a non-self-executing treaty.

Therefore the authors recommend that to avoid confusion between the concept of non-self-executing treaty and self-executing treaty, it is necessary to add an additional provision in a product of ratification either by Law or Government Regulation, whereas these products shall hitherto add an clause which confirms that: any International Treaties that have been ratified by the Government of Indonesia will be binding prima facie without the need of implementing legislation, in so far the International treaty requires it. This clause would be closely linked with the incorporation doctrine, which bypass the requirement of transformation, and allows automatic integration into national law without the prerequisite of adoption through national legislation.

This enable the understanding that when a country has agreed to be bound to a treaty or an international custom which has been accepted by the international community, the officials of the state and its citizens are ipso facto bind to perform it without the need for formalities, unless the need of formalities are specified otherwise in an national provisions. ${ }^{17}$

This assertion would be especially effective if such provision were to be integrated and are included on the construction of the Indonesian draft of Law on International Treaties (revised Law of the Republic of Indonesia Number 24 of 2000) or further stipulated in the revised Article 11 of the 1945 Constitution, however due to the time constraint, a revision of laws or amendments to the constitution would be impossible, and thus would leave a state of uncertainty, thus the authors recommend an alternative solution by changing the construct and framework of the ratification legal regime in Indonesia.

The authors' research highlights the fact that the Indonesian Law on Ratification of International Treaty only contain 2 or 3 articles. The first article generally affirms the ratification of the treaty, while Article 2 regulates on the rules of reservation clause (if any) and Article 3 is usually on the date the law shall take effect/in force. ${ }^{18}$ This practice has become so common practice and in fact it was presumed a necessity, although such framework of ratification does not constitute as necessity, nothing in the Act No. 24 of 2000 (Law on International treaties) and in Act No. 12 of 2011 (Law on the Formulation of Legislation) that profess the prerequisite of such construction.

Further, Annex II point $\mathrm{F}$ of Law 12 of 2011 regarding "legislation drafting

17 Atip Latifulhayat, "Perjanjian Internasional dalam Konteks Relasi dan Interaksi anatara Hukum Internasional dan Hukum Nasional”, Paper, Focus Group Discussion Law Faculty Unair and Ministry of Foreign Affairs Indonesia, Surabaya 25 November 2011.

18 Some Ratification Act which only contains 2 Article will put a clause containing the revelation that this Act shall take effect on the date of its promulgation in Article 2. 
technique" states:

The Law on Ratification of International Treaties in essence consists of 2 (two) Articles which is, as follows:

(1) Article 1 contains the ratification of international treaty by attaching a copy of the statement contains the original text and its translation in Indonesian.

(2) Article 2 contains provisions regarding the entry into force. ${ }^{19}$

The term "[...] in essence consists of 2 (two) Articles" in the above standard could be interpreted that generally the process of ratification products only requires the stipulation of this 2 articles, however it is possible for legislators to add a few more clauses to the Ratification Act. On the other hand the actual purpose these attachement serve, is to further contains a description or norms that has already exist in the legislation. ${ }^{20}$ In the context of the Law on Ratification the existence of such attachments are aimed to regulate the consistency of the formulation of the Ratification Act. With the addition of a clause that essentially asserts that any International Treaty which are already ratified by the Government of Indonesia will be binding without waiting for implementation legislation. ${ }^{21}$

\section{b. Harmonization of International Treaties Provisions with National Laws}

The obligation to harmonize national law with international law is explicitly prescribed in the Vienna Convention 1969 on agreements in Articles 27 and 46. Both of the article prescribe the rule that stipulates that, a state party that had wilfully entered into an international agreement or treaties, shall not justify non-compliance or violations to its treaty commitments vis-à-vis her own national law.

There is however certain exception to the above principle, is that if the violation or non-commitment of an international was caused by the performance or respect of an national law that are fundamentally important. As exemplified in the Permanent Court of International Justice (PCIJ) in the case Polish Nationals in Danzig on 4 February 1923 between Poland and Danzig 22 Which in this case both of the country has its own mechanism and procedures to harmonize the rules of international law into national law.

The consequences of the existence of such precedent, is that there are requirement and prerequisite under international law that forces state parties to adopt means of harmonization or adjustment of a ratified international instrument to a national legislation. To analyze Indonesia's position on this principle, it is required to analyze 2 perspective, which is:

\section{Perspective of National Legislation} Nothing in Law No. 24 of 2000 had specifically set out the requirement of prior harmonization and adjustment of ratified international agreement or treaties into the national legal system International Treaties, nor any article of the same nature, The absence of provisions

19 Annex II point F of Law 12 of 2011 regarding Establishment of Legislation (State Gazette of The Republic of Indonesia Year 2011 Number 82, Supplement to State Gazette of The Republic of Indonesia Number 5234).

20 The function and role of an attachment is indeed regulated in Figures 192 and 193 Appendix I of Law 12 of 2011 which in essence provides that in the case of legislation requiring the annex, it is stated in the torso that the attachment is an integral part of the Regulations. The attachments may contain, among other descriptions, lists, tables, images, maps, and sketches.

${ }^{21}$ In this context if the treaty were ratified/accessed by the Indonesian government in the category of treaty that require the implementation legislation, one clause must mandate the establishment of legislation body as implementation of the Convention in detail. Even if the appointment of an institution that responsibility is necessary and time limits of tolerance in its establishment.

22 On 4 February 1932, the Court (10 to 4) advised that the treatment of Polish nationals in Danzig must be decided solely by reference to art. 104(5) of the Treaty of Versailles and art. 33(1) of the Convention of Paris (and also if necessary, by reference to other treaties or rules of ordinary international law), but not by reference to the Constitution of Danzig, and that consequently Poland could not submit to organs of the League disputes concerning the application to Polish nationals of the Danzig Constitution and other Danzig laws, unless such disputes is the violation of Danzig's international obligations towards Poland arising either from treaty provisions in force between them or from ordinary international law. 
which expressly mandates the harmonization of international law that have been ratified/ acceded contributed to the dormancy of postratified international agreements and treaty.

Perspective of Practice in Indonesia, there are an abundance of dormant international agreements and treaties that had been ratified, and have not been followed by alignment process in national law. This stacks of dormant international agreements causes uncertainty to which international treaty are applicable and binding in the case where there are 2 or more legal products regulating the same materials. For example, Indonesia ratified United Nation Convention on the Law of the Sea 1982 which was integrated by Indonesia vis-à-vis Law Number 17 of 1985. However under the UNCLOS Ratification Data in United Nations, Indonesia was only declared state parties of UNCLOS since 3 March 1986, ${ }^{23}$ which at the time the Governmental Regulation Number 4 Year 1960 was still applicable.

Both of this legal products are equally binding for Indonesia, however there cannot be duality of law, lest it would create legal uncertainty, and ratification of international products does not necessarily negates the applicable and older legal regime. Both UNCLOS and Indonesia's Government Regulation regulate the same things regarding the archipelagic nation. But between these two legal products, there are several differences, one of which is associated with the determination of archipelagic sea lanes passage which was not accommodated in Law No. 4 of of 1960.

The above case illustrates that Indonesia have not successfully implemented harmonization of international treaty that had been ratified/acceded by Indonesia, to this extent, even the database of the International Treaty in the Ministry of Foreign Affairs has not been able to show any significant harmonization between Treaties/Agreement that had been ratified/acceded with the respective national law.

Therefore the authors recommend that that towards treaties that had been ratified or acceded, the government should maximize the plan for integration and harmonization of such commitment into national legal framework. It would altogether well if such provision contains: Firstly, Harmonizing Provision which mandated that any provisions of international treaties are to be adjusted in a way that are consistent to the national laws (specifically ratified by Ratification Laws), Secondly, Time range or time limit to conduct adjustments. Thirdly, Clause of Appointment of agencies responsible for adjustments. And lastly, a transitional provisions that provide legal certainty during the existence of dual laws.

The aforementioned clauses should ideally also be contained in the Law on International Treaties, which should be given a its own section, particularly a section that are specifically meant to cover questions relating to harmonization and integration, The best solution other than this would be an actively accommodate future ratification products with harmonization clause.

\section{c. Creating Implementation Legislation for International Treaties}

Not all international treaties are nonself-executing treaty that requires a specific implementation legislation to allow them to transform into an applicable legal product. Some treaties have the characteristics of selfexecuting, meaning that the implementation of such treaty does not require implementation

Ratification status see on Santiago Vilallpando, "Treaty Section", http://legal.un.org/ola/div_treaty.aspx?section=treaty, accessed on 27 Desember 2013 
legislation and could be executed upon ratification.

Determination of whether an international treaty is self-executing or non-selfexecuting, is contained within the treaty itself, several international treaties may explicitly mandates the establishment of a national legislation may be identified as a non-selfexecuting thus calling for an implementation regulation to be provided by the state parties as a national framework which the treaty shall operates. ${ }^{24}$ Likewise, if the clauses in the agreement does not specifically mandate the establishment of a national legislation, it can be said the agreement is self-executing which means it can be directly implemented or operationalized post a state's ratification/ accession.

From the perspective of national legislation, it can be seen that other than the lack of mandates of implementation legislation as argued above in discussing Law No, 24 of 2000, other ratification of other international treaties/agreement also tends to not include mandates to create implementation legislation. As exemplified in the Law Number 12 Year 2005 on the Ratification of Covenant on Civil and Political Rights, or the Law Number 29 Year 1999 regarding Convention on the Elimination of All Forms of Racial Discrimination 1965, which both do not point to an implementation legislation, but rather only contain obligation for promulgation following ratification.

\section{Therefore the authors recommend} that :

1) To regulate mandatory implementation legislation in a national level for acceded/ ratified international commitments, in order to ensure performance and participation not only from the government, but also any third party organization.

2) The requirement of maximum range of time, and maximal adjustment period, and methods to appoint institutions in charge in performing these obligations.

Similar to the previous recommendation, this assertion clause should be regulated in Law on International Treaties to promote nationwide implementation legislation as a means of fulfillment of international obligation. Additionally noting that Law No. 24 Year 2000 do not remotely discuss regarding implementation legislation. Then as a solution it would be preferable that an additional operative clause to be attached to products of ratification/accession either in the form Ratification Law or Presidential Regulation. This accommodation is feasible because the product of ratification/accession has no limit for these additions as the authors have previously described.

d. Registration and Publication of The Participation to International Treaties

Article 81-83 and 102 of the 1969 Vienna Convention sets the obligation for states to register and publicize its international treaties that a particular state has ratified immediately after accession/ ratification to the UN Secretary General for archiving. Although non-performance of this obligation does not impact the validity of international treaties, but non-performance of this obligation will only have implications for the inability to use the international treaty as a legal basis in the entire organs of the

\footnotetext{
24 Beberapa contoh perjanjian internasional yang mewajibkan implemtation legislation adalah 1) Part II, Article 2 International Covenant on Civil and Political Rights, 2) Article 88 Rome Statute of the International Criminal Court, 3) Convention on the Prevention and Punishment of the Crime of Genocide, 4) Article 4 and 5 Convention against Torture and Other Cruel, Inhuman or Degrading Treatment or Punishment, 5) Article 2 (1) d International Convention on the Elimination of All Forms of Racial Discrimination
} 
United Nations.

From the perspective of national

legislation it can be seen that the commitment of the Government of Indonesia in undertaking this particular obligation to Register and Publicize its Participation in an International Treaty is already satisfactory this is evident from the provision within Chapter V, Article 17 of Law No. 24 of 2000 on International Treaties. Article 17 (3) that stipulates: The Minister is responsible for archiving and maintaining the original text of the treaty concluded by the Government of Indonesia and compiling a list of official documents and publish them in the secretariat of the international organization of which Indonesia is a member. This is an evidence that Indonesia had sufficiently accommodated this obligation.

From the perspective of practice in Indonesia, one of the indicators to assess whether the obligation of registration and publication of the participation of a state in international treaties have been implemented optimally is by comparing the publication of Indonesia's participation in international treaties issued by the Ministry of Foreign Affairs and United Nations Treaty Collection (UNTC) ${ }^{25}$. According to the November 2016 data, the Foreign Minister of Indonesia noted that there are 4872 international agreement had been concluded, While UNTC noted that Indonesia are a state party to 1000 international agreement ${ }^{26}$ The apparent disparity between registered/publicized agreement noted by UNTC and the Data by Foreign Ministry of Indonesia shown that this obligation had not yet been satisfactory.
Therefore the author recommends in regard to the implementation of the obligations to register and publicized state participation in international treaties requires more improvement, such provisional rule should also be integrated in the product of ratification/accession either in the form of laws and regulations or presidential regulation.

\section{e. Estabilshment of a National Agency Mandated to Implement Interna- tional Treaties}

Several international treaties entails the obligation of an National Implementing Agency mandated to ensure efficacy of implementation of treaty, one example of such special body is ASEAN Charter. Although not many international treaties entails this obligation, and more apparent in treaties that involve creation of an international organization/ committee. For example, in Part V, Article 17 of the Convention on the Elimination of All Forms of Discrimination against Women New York, 18 December 1979 mandated the establishment Committee on the Elimination of Discrimination against Women.

In the perspective of national legislation it can be seen that the commitment in fulfilling this particular obligation by the government is still lacking. As none of the provision of Law No. 24 of 2000 regulates the establishment of an National Agency to implement international treaties. However in the perspective of practice in Indonesia, Indonesia has shown degree of performance, as seen in the implementation of the Article 13 of ASEAN Charter in Indonesia. Article

25 UNTC is the publication of a collection of international agreements published by the Treaty Section, United Nations Office of Legal Affairs in accordance main functions of the Treaty Section, one of which is Issuing publications pursuant to Article 102 of the Charter and the related General Assembly Regulations, developing and maintaining an electronic database and information system to facilitate access to treaty information and providing advice and information on treaty law and related matters. Look Santiago Vilallpando, "Treaty Section", http://legal. un.org/ola/div_treaty.aspx? section=treaty, accessed on 27 Desember 2013.

26 Santiago Vilallpando, Ibid. 
13 of the ASEAN Charter requires member countries of ASEAN to establish a national secretariat that has specific tasks as set out in the Charter, of which Indonesia have ratified by Law No. 38 of 2008 and was registered to the ASEAN Secretariat on November 11, 2008. Shortly after ratification Indonesia promptly established the National Secretariat on November 11, 2008.

Although national law does not have a specific regulation regarding establishment of national implementing agencies for purposes of fulfillment of international treaty, however in practice the obligation has been adequately conducted by Indonesia. This fact in view of the authors is actually easily fulfilled as there is only small numbers of international treaties that provide specific mandate for the establishment of national institutions.

\section{f. Submitting Reports Regarding the Implementation of Provisions of International Treaties}

Other mechanism for monitoring of international treaties implementation, are the requirement of submitting reports of implementation. Reports of implementation records the state parties follow-up action and programs that had been implemented by the government following the ratification, one example of treaties requiring reports submission are ICCPR (International Covenant on Civil and Political Rights).

In the perspective of national legislation, there are no legal framework that sets the obligation of reports submission as a means of implementation of international treaties, however from the perspective of practice in Indonesia it is seen that this obligation had been implemented properly. It can be seen practical application of the ICCPR in Indonesia, whereas after Indonesia's ratification of ICCPR through Law No. 12 of $2005^{27}$ Indonesia's had periodically and regularly submit reports of implementation in accordance to Article 40 of the ICCPR. Such obligations have been implemented by the Government of Indonesia where the authority delegated to the Ministry of Justice and Human Rights in cooperation with the Ministry of Foreign Affairs.

Although remains outside of national legislation, but it can be concluded that Direktorak Kerjasama HAM of Indonesia faces hindrance in formulating such reports and the consequent submission to OHCHR, which was primarily caused by: difficulties in data collection, and the instrument of ratification of ICCPR which is Law No. 12 Year 2005 does not set a strict definition and sets procedures of implementation, as such there are significant amount of rights protected under ICCPR that has not been fulfilled.

Therefore, as a recommendation from the authors, the government should create an additional provisions or statements in the Ratification Law or in the ratification products, that declares that implementation of treaty obligation must be done under due observation and are reported to the Government under the coordination of Ministry of Justice and Human Rights in collaboration with Ministry of Foreign Affairs. This assertion can be accommodated either in the Law or in the international treaties ratified international treaties product. In the ratification law for example, it is possible to add a clause containing such an assertion.

Ministry of Justice and Human Rights, 2010, Laporan Pelaksanaan Rapat Koordinasi dalam Rangka Implementasi Instrumen HAM yang telah Diratifikasi Indonesia (Kovenan Hak Sipil dan Politik) Penyempurnaan Hasil Implementasi, Tahun Anggaran 2010, Ministry of Justice and Human Rights, Jakarta, p. 13. 
2. Moral Obligation

\section{a. Ratifiying Signed International Treaties}

States involved in the formulation of the material substance of an international treaty is generally states that carries a vested interest in a particular issue. Signing an International treaties represents acceptance or approval over the substance of the treaty ${ }^{28}$ In other words, what is stipulated in an international treaty has been deemed sufficient to protect the interests of the state concerned. In Vienna Convention 1969 Article 10 provides that a signatory to an international treaty text which requires ratification, merely officiates the treaty, however signature does not directly translate to the obligation ratification.

From the perspective of national legislation, there are no specific law regarding the obligation to ratify a signed international agreements because in principle ratifying a signed treaty is not a legal obligation, but rather a moral obligation. Under the perspective of practical implementation Indonesia rarely take specific notice to moral obligation, an interesting testament to this attitude the ASEAN Agreement on Transboundary Haze Pollution (AATHP). Indonesia have affixed their signature to the Convention on 10 June 2002, but until January 2014 Indonesia is the only country in ASEAN which has yet to prove its commitment to be bound by the treaty. Whereas on the other hand Indonesia is a country that has contributed greatly to the cause forest fires that impact neighboring countries in ASEAN.

\section{b. Conduct Dissemination of Interna- tional Treaties to Indonesians}

Based on General Assembly

Resolution No. 2698 (XXV), UN member states are advised to carry out dissemination of the International Products ratified by a state to allow knowledge every citizens. This is aimed to avoid the ignorance of the citizens of their own rights and of the law, and to introduce public understanding of the material substance of an international treaties ratified by state concerned.

From the perspective of national legislation, the obligation to disseminate international treaties to citizens have been accommodated in the Article 10 and Article 11 of Law No. 24 In 2000, the use of the Law or the Presidential Regulation and also in Article $95^{29}$ Law No. 12 of 2011 regarding Formulation of Legislation ${ }^{30}$, all legislation must be disseminated in promulgation in the State Gazette, Official Gazette, Regional Gazette and supplemented in Regional and Local News, and all promulgation of law including all international treaty ratified shall be translated in Indonesia Language, as seen in Article 31 of Law No. 24 of 2009 on the Flag, Language, and State Emblem. In addition, post-ratification, translation of the material substance of international treaties that have been ratified earlier would have been done.

From the perspective of practical application in Indonesia related to the obligation to disseminate international agreements to citizens, is already adequate. One indicator that shows the implementation of these obligations is adequate is since October 15, 2009 the Government through the Ministry of Foreign Affairs has published a web named "Database International Agreements" which allows all Indonesian citizens to know the

28 I Wayan Parthiana, 2002, Hukum Perjanjian Internasional, Mandar Maju, Bandung, p.22.

29 Legislation script is disseminated should be a copy of the manuscript that has been promulgated in the State Gazette of the Republic of Indonesia, State Gazette of the Republic of Indonesia, the Official Gazette of the Republic of Indonesia, the Official Gazette of the Republic of Indonesia, the Regional Gazette, Supplement Regional and Local News.

30 Based on Article 7 paragraph (1) Law 12 of 2011 regarding Establishment of Legislation, included in the hierarchy Regulation Legislation are; 1945 Constitution of RI, PCA Regulation, Law or the Government Regulation in lieu of Law, Government Regulation, Presidential Regulation, Provincial Regulation and Regulation City District. 
Government of Indonesia participates in and also provide access to treaty text in English and in Bahasa Indonesia.

The downside is, access to internet are not widely shared and thus the writer, urges the government to conduct socialization directly to the area affected with Indonesia's participation on the international treaty. The significance of the direct socialization is it may also allow government to clearly elaborate the content of the international treaties in better detail.

\section{Conclusion and Recommendation}

\section{Conclusion}

Based on the results of the discussion, this research can conclude that in relation to the obligation of fulfillment of an international treaty by Indonesia indicates the existence of obligation to:

a. Respect and uphold the provisions of international treaties and implement them in good faith, as regulated in Article 4 paragraph (1) Law No. 24 Year 2000, although in practice this obligation has not been fully implemented.

b. Indonesia tends to undermine the position of international treaties, even after ratification, to better integrate international treaties in Indonesia's legal framework, a process of ratification must be followed by process of integration into law, either via implementation regulation, or by equipping executorial provisions in the ratification products.

c. Registration and publication of the participation to international treaties, as stated in Article 17, Chapter V of Law No. 24 of 2000 regarding International Treaties, has not been fully optimized.

d. Establishment of a national agency mandated to implement international treaties, as the Law on International Treaties have not established such obligation. In practice this obligation has been carried out properly. e. Submission of Reports on the implementation of international treaties, there are no obligation to conduct such under national legal frameworks. Although in practice the obligation has seen practice conducted, however there are a lack of participation as the submission of these reports are the responsibility of the Ministry of Justice and Human Rights in cooperation with the Ministry of Foreign Affairs.

f. Mandatory ratification for all signed international treaties, as practice shown it does not manifest as obligation in national legislations, and remain to appear as moral obligation deemed to be attached to each Treaty.

g. Conducting Dissemination of International Treaties to Indonesians, where in national legislations have been regulated in Article 95 of Law No. 12 of 2011 on the Formulation of Legislation and Article 31 of Law No. 24 of 2009 on the Flag, Language, and State Emblem. Meanwhile, while the level of practice has been implemented through publishing of the website "Database International Treaties".

\section{Recommendation}

Based on the result of the discussion, in this research the authors recommend:

a. To maximize the fulfilment of international treaties obligation, it is necessary to add a special clause in the ratification of the treaty, either in the form Ratification Law or the Presidential Regulation which contains that:

1) Every International Treaty ratified by the Government will be binding to Indonesia including its citizens immediately without the requirement of any other legislation, insofar the treaty indicates otherwise.

2) Actively harmonizing and adjusting the provisions of ratified/ acceded international treaties with relevant national law. 
3) The government must immediately manufacture implementation legislation in the national level, in so far required by the treaty.

4) Every International Treaty ratified by the government shall be registered and published to the UN Secretariat as soon as possible.

5) The government must immediately establish a national agency mandated to implement international treaties to which Indonesia is a state party. b. To maximize the accomplishment of the moral obligation for the fulfillment of international treaties, The Indonesian government should enhance its awareness that fulfillment of treaty obligation allows positive image building for Indonesia, additionally an active socialization agenda to areas directly affected by the treaty would improve societal awareness, and thus overall efficacy.

\section{REFERENCES}

\section{A. Books}

Dalton, E., 2006, National Treaty Law and Practice, Martinus Nijhoff Publishers, Leiden.

Glahn, Gerhard Von, 2013, Law Among Nations: An Introduction to Public International Law, Longman, Boston.

Hartono, Sunaryati, 2006, Penelitian Hukum di Indonesia Pada Akhir Abad Ke-20, Alumni, Bandung.

Marzuki, Peter Mahmud, 2010, Penelitian Hukum, Kencana Prenada Media Group, Jakarta.

Ministry of Justice and Human Rights, 2010, Laporan Pelaksanaan Rapat Koordinasi dalam Rangka Implementasi Instrumen HAM yang telah Diratifikasi Indonesia (Kovenan Hak Sipil dan Politik) Penyempurnaan Hasil Implementasi, Tahun Anggaran 2010, Ministry of Justice and Human Rights, Jakarta.

Parthiana, I Wayan, 2002, Hukum Perjanjian Internasional, Mandar Maju, Bandung. , 2005, Hukum Perjanjian

Internasional Bagian 2, Mandar Maju, Bandung.

Simpson, John and Weiner, Edmund (eds), 1991, The Oxford English Dictionary (2 ${ }^{\text {nd }}$ ed), Oxford University Press, Oxford.

Suryokusumo, Sumaryo, 2007, Studi Kasus Hukum Internasional, Penerbit Tatanusa, Jakarta.

\section{B. Government Regulation}

Law No. 24 of 2000 of the Republic of Indonesia regarding International Treaties (State Gazette of The Republic of Indonesia Year 2000 Number 185, Supplement to State Gazette of The Republic of Indonesia Number 4012).

Law No.10 of 2004 regarding Establishment of Legislation (State Gazette of The Republic of Indonesia Year 2004 Number 53, Supplement to State Gazette of The Republic of Indonesia Number 4389).

Law No. 12 of 2011 regarding Establishment of Legislation (State Gazette of The Republic of Indonesia Year 2011 Number 82, Supplement to State Gazette of The Republic of Indonesia Number 5234).

The Vienna Convention on The Law of Treaties.

The New York Convention 1958.

Treaty of Versailles.

The Convention of Paris.

\section{Journal Articles}

Park, William W., "Treaty Obligation and National Law", Hastings Law Review, Vol. 58, No. 1, 2012.

Dewanto, Wisnu Aryo, "Difficult to Implement the Law Review Regarding Foreign Arbitral Awards In Indonesia", Yustika Journal, Vol. 7, No. 2, December 2004. 


\section{Paper}

Latifulhayat, Atip, "Perjanjian Internasional dalam Konteks Relasi dan Interaksi anatara Hukum Internasional dan Hukum Nasional", Paper, Focus Group Discussion Law Faculty Unair and Ministry of Foreign Affairs Indonesia, Surabaya 25 November 2011.

\section{E. Internet Articles}

Basis Data Perjanjian Internasional, Indonesia Foreign Minsitry, accessed November
2016.

Coal, Suleman, "Rejection of Foreign Arbitral Awards in Indonesia (Study of PT Nizwar v. Navigation Maritime Bulgare)", http:// batubarasuleman.blogspot.com/2010/11/ penolakan-putusan-arbitrase-asing-di.html, accessed on 27 Desember 2013.

Vilallpando, Santiago, "Treaty Section", http://legal. un.org/ola/div_treaty.aspx? section=treaty, accessed on 27 Desember 2013. 